http://www.pakjas.com.pk

\title{
BIOCHEMICAL AND MOLECULAR CHARACTERIZATIONS OF SALT AND PHYTOHORMONES-INDUCED CHANGES IN ROOTS AND SHOOTS OF RICE SEEDLINGS
}

\author{
Wenyi Wang ${ }^{1}$, Mengyun $\mathrm{Xu}^{1}$ and Muhammad Jamil ${ }^{1,2, *}$
}

\author{
${ }^{1}$ Institute of Crop Science, College of Agriculture and Biotechnology, Zhejiang University, Yu-Hang-Tang Rd.388, \\ Hangzhou 310058, China; ${ }^{2}$ Department of Biotechnology and Genetic Engineering, Kohat University of Science and \\ Technology, Kohat 26000, Pakistan. \\ *Corresponding author's e-mail: dr.jamil @ kust.edu.pk
}

BTF3, initially identified as a basal transcription factor, has been recognized to be involved in plant growth and development. But, its function remains mostly unknown in abiotic stress regulation in plants. The present study describes salt stress and phytohormones induced changes in cell homeostasis and different variants of basal transcription factor (BTF3) in root and shoot of rice using FT-IR and semi-quantitive PCR approaches. Both phytohormone ABA (5 and $10 \mu \mathrm{M}), \mathrm{GA}_{3}(50$ and $100 \mu \mathrm{M})$ and salt stress $(50$ and $100 \mathrm{mM})$ did not induce any significant decrease in germination. However, decrease in germination rate, root and shoot lengths were observed with increasing concentration of $\mathrm{NaCl}$ and $\mathrm{ABA}_{\text {while }} \mathrm{GA}_{3}$ enhanced shoot length. The fourier transformed infrared (FT-IR) results showed that protein, carbohydrate, lipid, and cell wall pectin content increased in the shoot, indicating that the carbon assimilation was not affected at the early seedling stage. However, in root, the protein, carbohydrate, lipid synthesis and cell expansion ceased with both phytohormone and salt stress. Semiquantitative PCR analyses demonstrated that different variants of OsBTF3 were constitutively expressed in different tissues and organs. The expression of Osj3g1BTF3, Osj3g2BTF3 and Osj10gBTF3 were primarily constitutive and generally modulated by $\mathrm{NaCl}, \mathrm{ABA}$ and $\mathrm{GA}_{3}$ stress in both root and shoot at the early seedling stage, suggesting that they are probably differing from each other in biological function.

Keywords: BTF3, homologs, abiotic stress, macromolecule, Oryza sativa.

\section{INTRODUCTION}

Plant responds to multiple environmental factors by various mechanisms, including changes in physiological, biochemical and molecular processes. To cope with these factors, plants are linked to metabolic alteration that guide to the accumulation of protein, starches and lipids (Koster and Leopold, 1988) during seed germination and transferring these to different organs, where they are necessary for growth (Mayer and Poljakoff-Mayber, 1975). FT-IR could be used to recognize the structure of unidentified composition or its chemical group, and the intensity of the IR spectra linked with molecular composition or content of the chemical group (McCann et al., 1992; Surewicz et al., 1993). The accumulation of these compatible solutes is regulated by different genes, which are stimulated by abiotic stresses. They contain numerous transcription factors (TFs) focus on the role in the multiple physiological mechanism (Zhou et al., 2010; Hussain et al., 2011). The basal transcription factors 3 (BTF3) is one of the important transcription factors and it play role in various biotic and abiotic stress processes (Li et al., 2009; Li et al., 2012a; Gorantla et al., 2005; Wang et al., 2012).
BTF3 linked with the translation initiation factor (iso) $4 \mathrm{E}$ (eIFiso4E) in Arabidopsis, and produced the translation initiation complex eIF(iso)4F (Freire, 2005). In Nicotiana benthamiana, NbBTF3-silenced plants demonstrate an abnormally developed phenotype. Similarly, Ma et al. (2012) observed that the expression of the mitochondrial and chloroplast encoded genes were markedly decreased in TaBTF3-silenced wheat transgenic plants. It was observed that BTF3 gene play a role in hypersensitive response (HR) cell death and might function as aTFs in the nucleus through transcriptional regulation of HR-related gene expression in Capsicum annuum(Huh et al., 2012). Wang et al. (2012) recently observed that BTF3regulates the transcription of various proteins in rice. They also reported two otherBTF3related genes Osj3g1BTF3 and Osj3g2BTF3. However, the function of Osj3g1BTF3 and Osj3g2BTF3 in abiotic stress regulation in plants is not yet reported. In the present work, an investigation was made to evaluate the role of $\mathrm{GA}_{3}, \mathrm{ABA}$, salt on cell homeostasis and homologs or splicing variants of OsBTF3s at seedling stage. OsBTF3s were transcriptionally regulated by salt, $\mathrm{GA}_{3}$ and $\mathrm{ABA}$ in root and shoot at seedling stage. 


\section{MATERIALS AND METHODS}

Seed germination:The experiment was done in green house of Zhejiang University, China. Seeds of Oryza sativa L. subsp. japonica line Nipponbare was germinated on double filter paper in Petri plates moisten with distilled water(control), $\mathrm{NaCl}(100$ and $200 \mathrm{mM}), \mathrm{GA}_{3}$ (100 and $200 \mu \mathrm{M})$ and ABA (5 and $10 \mu \mathrm{M})$. The seeds were incubated in dark condition at $30 \pm 2^{\circ} \mathrm{C}$. Seed germination $(\sim 2 \mathrm{~mm}$ radical) was recorded after every 12 hours up to 7 days. Seedlings were separated into shoots and roots for measuring root and shoot lengths after 15 days of germination.

FT-IR spectroscopy:The root and shoots were taken from different seedlings and were used as one sample. Then the samples were instantly oven dried at $80^{\circ} \mathrm{C}$ for 2 days. Small beads were prepared by mixing leaves powder $(2 \mathrm{mg})$ with $\operatorname{KBr}(1: 100 \mathrm{p} / \mathrm{p})$ for FTIR spectroscopy. Fourier transformed infrared (FTIR) spectroscopy (THERMO- NICOLET AVTAR-370, USA) was used to collect spectra. The IR spectra were measured between 400 and $4000 \mathrm{~cm}^{-1}$. Three spectra were collected from each sample and only one representative spectrum was shown in the results. Curvefitting of the original spectra was done with Origin 7 software. The FT-IR spectra between 3000 and $2800 \mathrm{~cm}^{-1}$ was chosen to analyze lipids. The IR spectra between 1800 and $1500 \mathrm{~cm}^{-1}$ was chosen to analyze proteins. The FT-IR spectra between 1200 and $1000 \mathrm{~cm}^{-1}$ was chosen to analyze carbohydrates.

RNA isolation from different tissues:Total RNAs was extracted from the fresh root and shoot of Oryza sativa L. under normal and stress conditions according to the manufacturer's instructions using Trizolreagent (Invitrogen). cDNA synthesis of first-strand was done using the M-MLV first-strand synthesis system (Promega).

Expression analysis using RT-PCR:Semi-quantitative PCR approach was used to check the expression of Osj3g1BTF3, Osj3g2BTF3 and Osj10gBTF3 in normal and stressed plants.

The semi-quantitative PCR was performed by using the method of Wang et al. (2012). The amplification profile consisted of $94^{\circ} \mathrm{C}$ for $5 \mathrm{~min}$, followed by 28 cycles of $30 \mathrm{~s}$ at $94^{\circ} \mathrm{C}, 30 \mathrm{~s}$ at $56^{\circ} \mathrm{C}$, and $30 \mathrm{~s}$ at $72^{\circ} \mathrm{C}$. Actin I gene in rice was used as an internal control. All reactions were repeated with at least three times. PCR products were separated on $1 \%$ agarose gel containing ethidium bromide, and photographed under UV light.

\section{RESULTS}

Seed germination and seedling growth:The final germination percentage was not affected by $\mathrm{GA}_{3}, \mathrm{ABA}$ and $\mathrm{NaCl}$ but the germination efficiency were reduced in the presence of $\mathrm{GA}_{3}, \mathrm{ABA}$ and $\mathrm{NaCl}$ in the medium as compared to control. Gibberellins promote seed germination, demonstrating that the endogenous GA concentrations affect germination efficiency than the $\mathrm{ABA}$ and salt stress. But ABA showed a considerable decrease in germination efficiency than salt (Fig. 1).

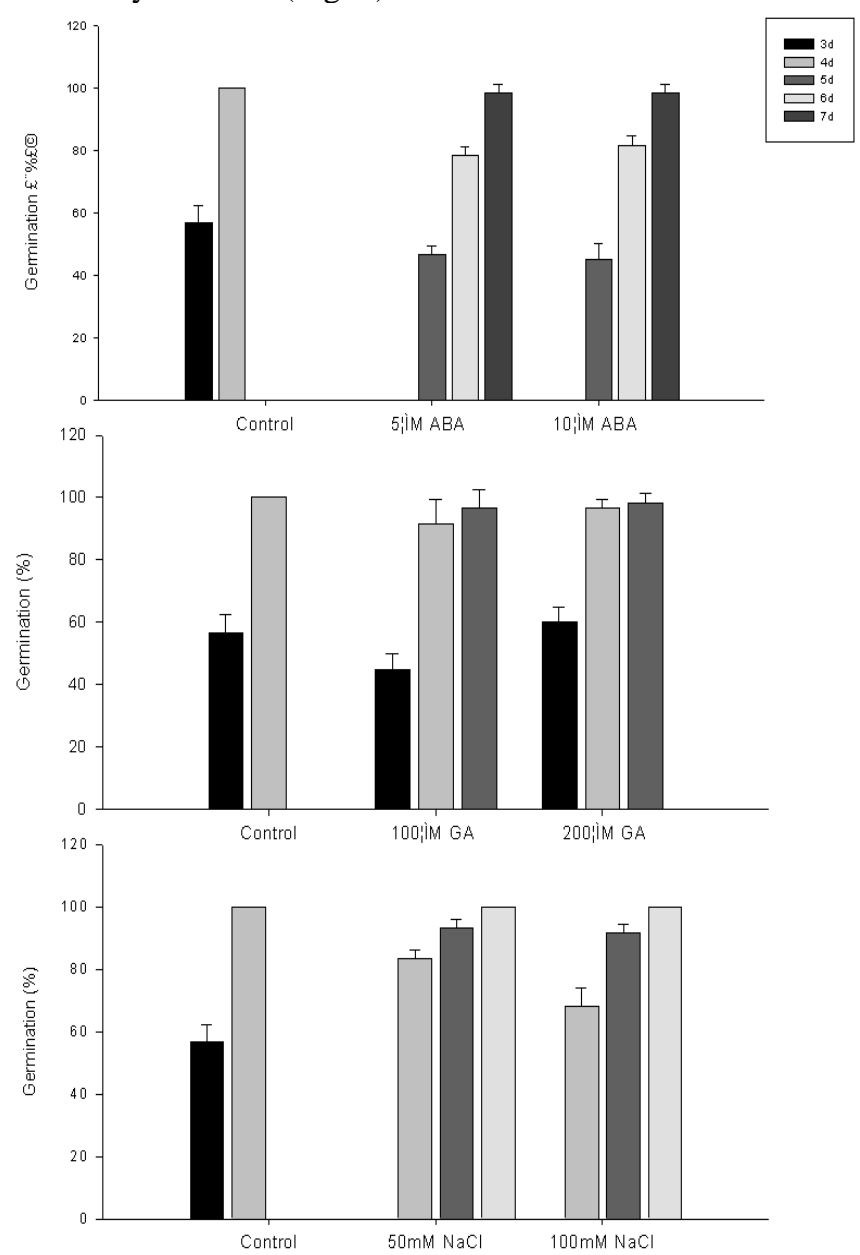

Figure 1. Effect of different concentration of ABA (A), $\mathrm{GA}_{3}(\mathrm{~B})$ and salt $(\mathrm{C})$ on seed germination of rice.

The root and shoot lengths decreased in response to increasing concentrations of $\mathrm{ABA}$ and $\mathrm{NaCl}$ (Fig. 2A,C; Fig. $2 \mathrm{CDEF}$ ). However, $\mathrm{NaCl}$ had a more negative effect on root and shoot than ABA. On the other hand, GA3 did not induce significant changes in root with increasing concentration of GA3, however, a considerable increase in the shoot was observed with increasing level of GA3 (Fig. 3B; Fig. 2A.B).

FT-IR monitors the changes in cell homeostasis:In this study, a variation was observed in the chemical composition of carbohydrate, protein, lipids and cell wall pectin during development in the root and shoot of rice seedling. The effects of the $\mathrm{ABA}, \mathrm{GA}_{3}$ and salt were analyzed in root and shoot by FT-IR spectrometry (Fig. 4 and 5). The IR spectroscopy revealed absorption peaks between 4000 and $1000 \mathrm{~cm}^{-1}$ on the root and shoot. Roots and shoots taken 
from rice seedlings produced great numbers of sharp absorption bands in the mid-IR region $\left(2,000-1,000 \mathrm{~cm}^{-1}\right)$ and end region (3000-2800 $\left.\mathrm{cm}^{-1}\right)$ indicating that roots and shoots have a rich chemical composition of carbohydrates, proteins, cell wall pectin and lipids.
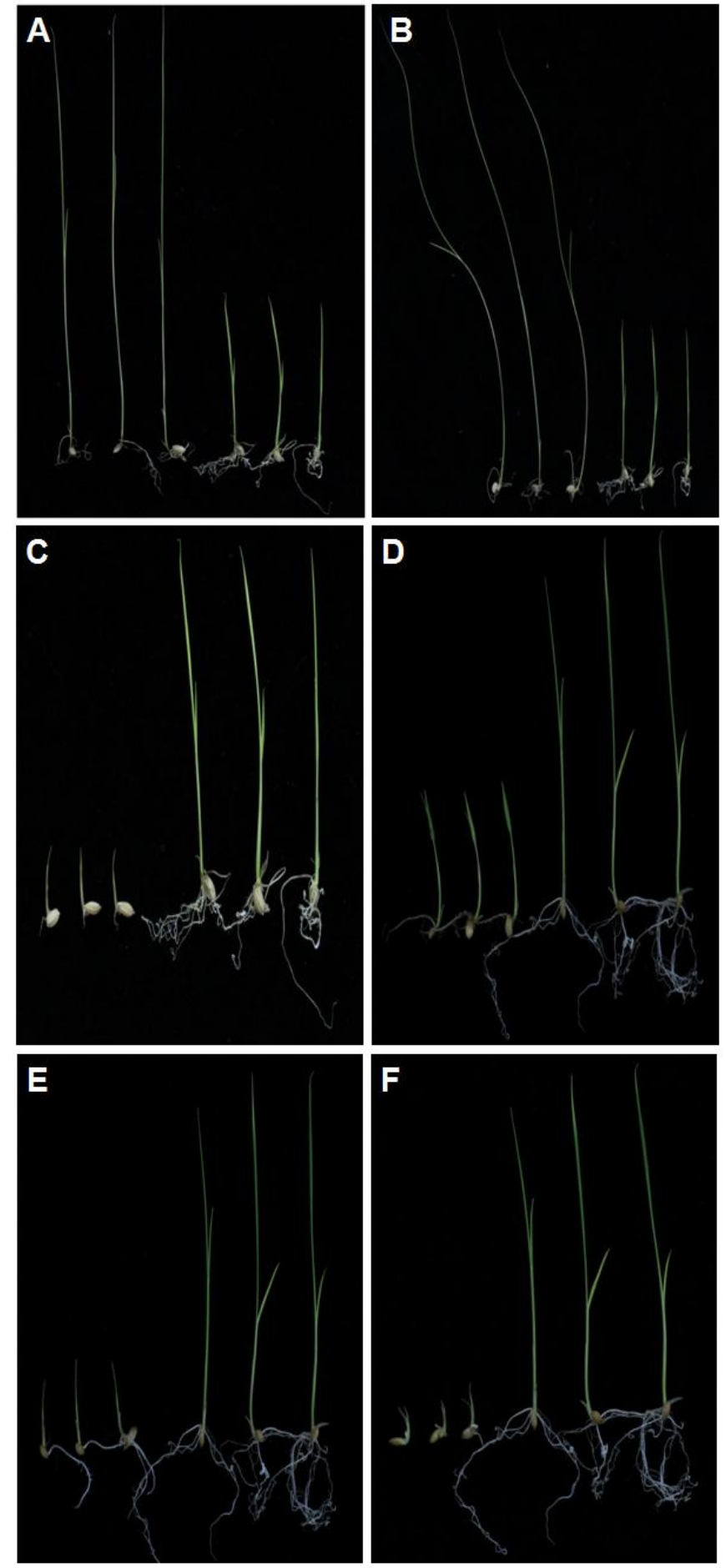

Figure 2. Effect of different concentration of $\mathrm{GA}_{3}, 100$ $\mu \mathrm{M}$ (A), 200 $\mu \mathrm{M}$ (B), salt, $50 \mathrm{mM}(\mathrm{C}), 100 \mathrm{mM}$
(D) and $A B A, 5 \mu M(E) ; 10 \mu M(F)$ on phenotype of rice. Right three are control and left three are treatment.
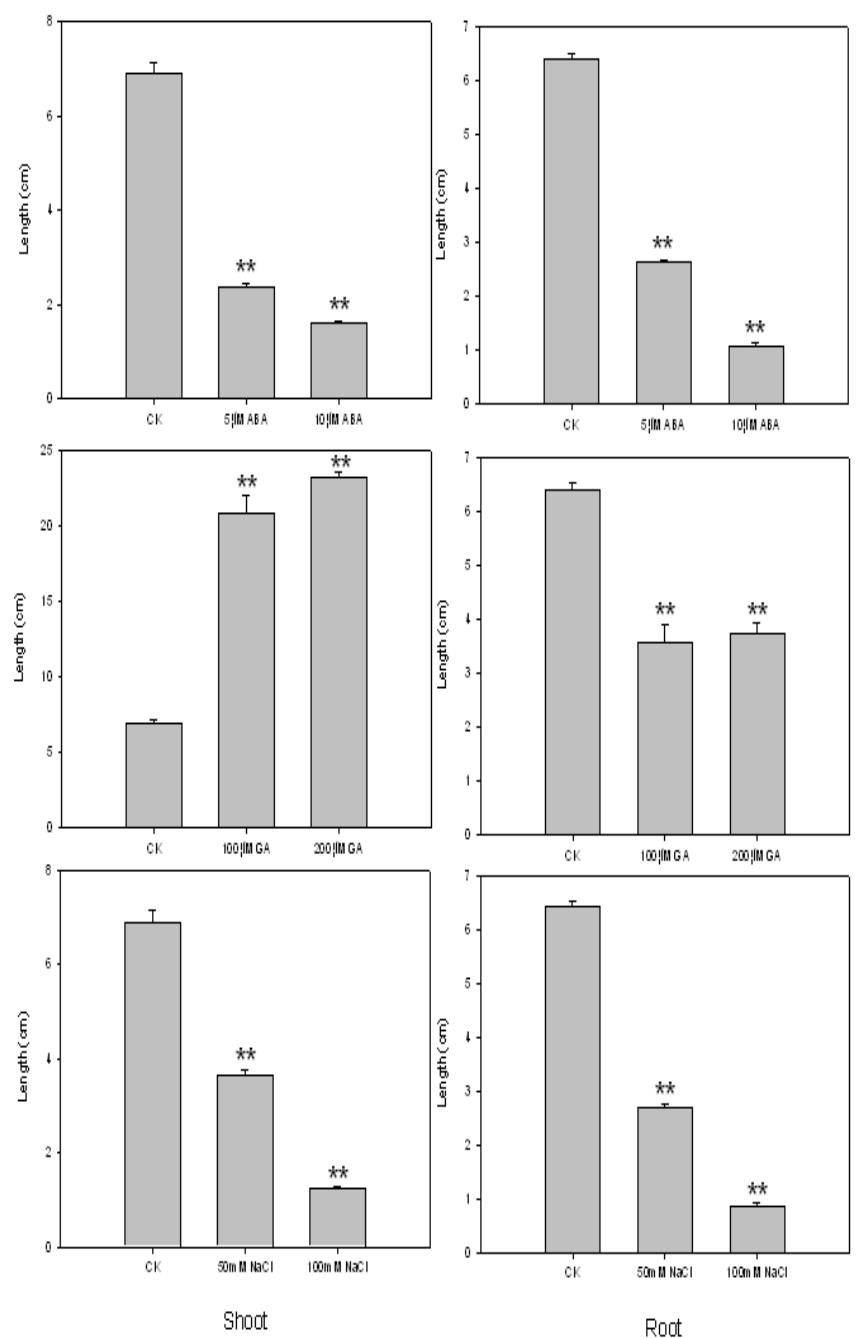

Figure 3. Effect of different concentration of ABA (A), $\mathrm{GA}_{3}(\mathrm{~B})$ and salt $(\mathrm{C})$ on root and shoot lengths of 15days old rice seedling.

Changes in carbohydrate and protein:As the FT-IR absorption peaks between 1200 and $1000 \mathrm{~cm}^{-1}$ generally take place from carbohydrates (Wei et al. 2009). Decrease in the absorbance ratio was observed in the IR spectra of carbohydrate in root with the increasing ABA level from 5 to $10 \mathrm{uM}$. Similarly, the accumulation of carbohydrates was decreased with an increase in $\mathrm{GA}_{3}$ concentration in the root, but this decrease was more at $100 \mu \mathrm{M}$ concentration. However, salt stress did not induce major changes in the FTIR absorption spectra of salt-stressed root, implying the carbohydrate did not accumulate obviously (Fig. 4). The FTIR spectra showed $\mathrm{ABA}, \mathrm{GA}_{3}$ and salt induced considerable increase in carbohydrate accumulation in the shoot with a 
corresponding increase in $\mathrm{GA}_{3}$ and salt concentration but ABA accumulate mainly at 5uM concentration (Fig. 5).
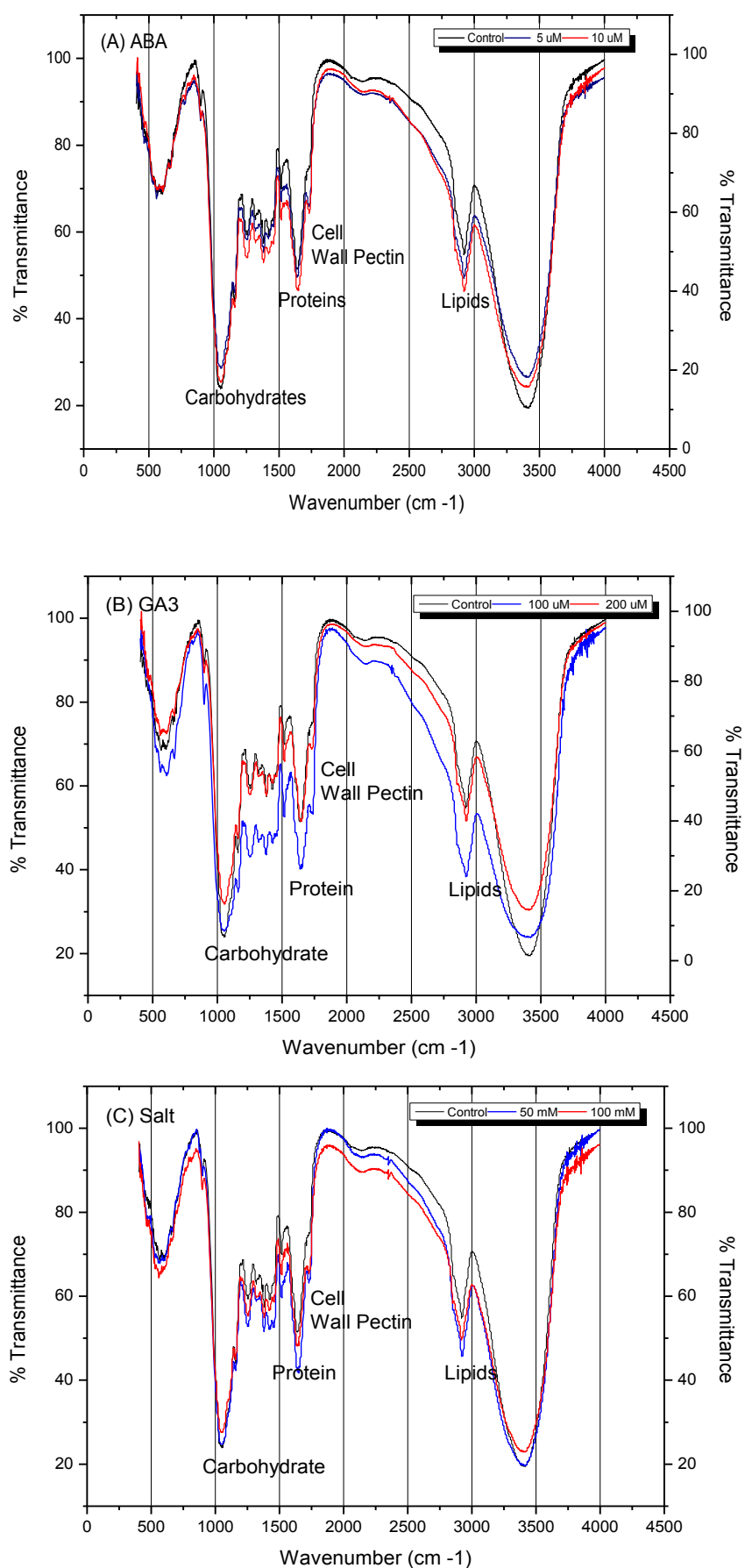

Figure 4. The effect of different concentrations of ABA (A), GA3 (B) and salt (C) on the FT-IR absorption spectra of 15 days old roots of rice plant. The major chemical constituents that contribute to the formation of bands in the particular wave numbers are carbohydrate, protein, cell wall pectin and lipids. At least three spectra were obtained from each sample and only one representative spectrum of each treatment is shown.
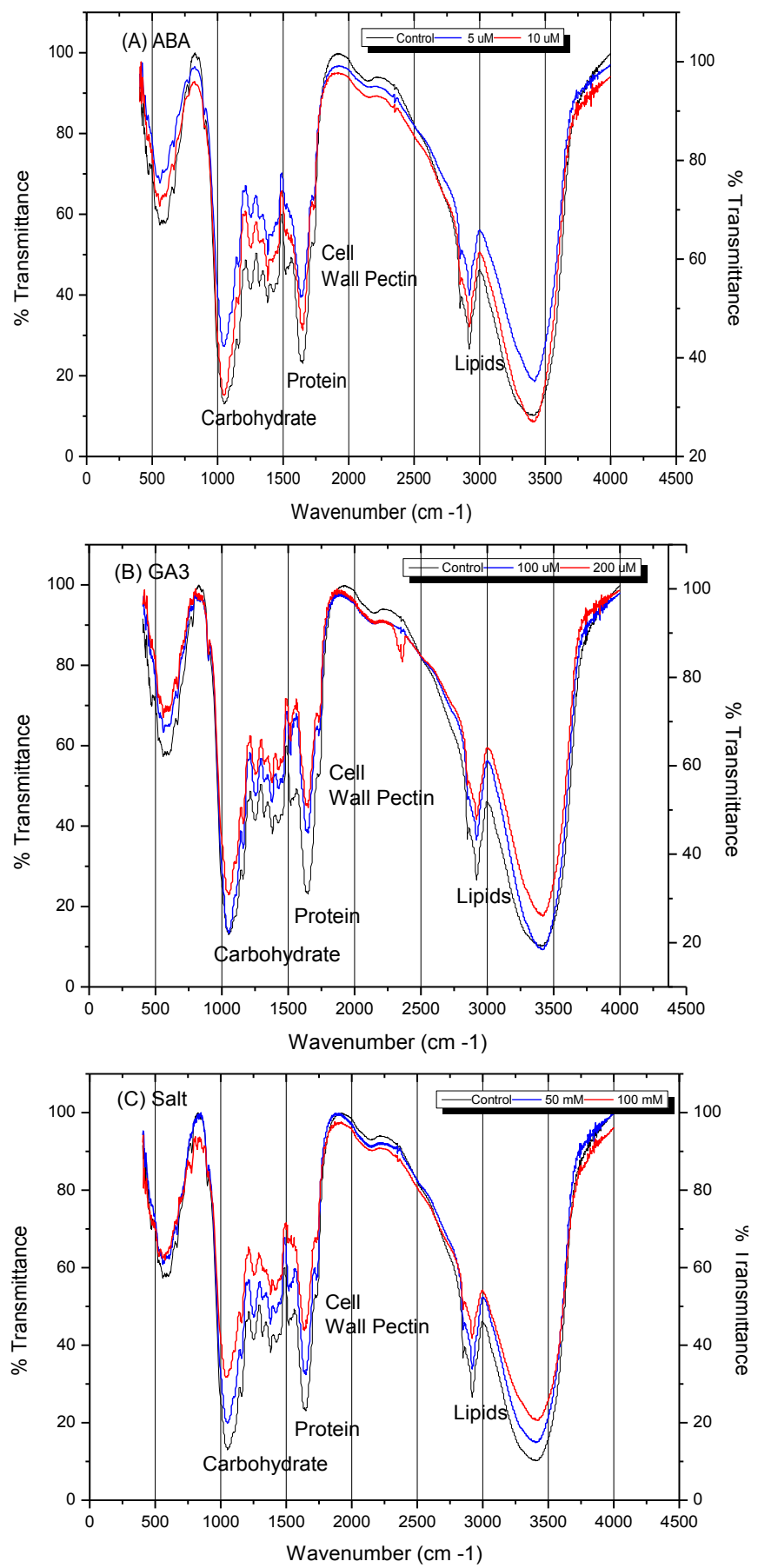

Figure 5. The effect of different concentrations of ABA (A), GA3 (B) and salt (C) on the FT-IR absorption spectra of $\mathbf{1 5}$ days old shoots of rice plant. The major chemical constituents that contribute to the formation of bands in the particular wave numbers are carbohydrate, protein, 
cell wall pectin and lipids. At least three spectra were obtained from each sample and only one representative spectrum of each treatment is shown.

The protein absorption peaks generally located between 1800 and $1500 \mathrm{~cm}^{-1}$ consisted of amide-I and amide-II (Surewiczet al., 1993; Stehfestet al., 2005), but sometime intermingle with other absorption peaks within this region (Wei et al., 2009). In protein, a decrease in band intensity was observed, indicating a considerable decrease in protein accumulation by the root with increasing $\mathrm{ABA}, \mathrm{GA}_{3}$ and salt level. This decrease was more at $5 \mu \mathrm{M}$ ABA, $100 \mathrm{uM} \mathrm{GA}$ and $100 \mathrm{mM}$ salt (Fig. 4). Though in case of shoot, a higher increase in protein accumulation was observed in shoot with the increase in $\mathrm{ABA}, \mathrm{GA}_{3}$ and salt concentrations, however in $\mathrm{ABA}$, the absorbance ratio of protein was more pronounced at $5 \mu \mathrm{M}$ ABA (Fig. 5). The data indicated that the protein and carbohydrate synthesis pathway in root is sensitive to $\mathrm{ABA}, \mathrm{GA}_{3}$ and salt stress as compared to shoot and uphold a higher ordered form of protein in the shoot at the early seedling stage.

Changes in cell wall pectin and lipids:The absorption band around 1743 or $1745 \mathrm{~cm}^{-1}$ represents cell wall pectin (Yang and Yen, 2005; Wei et al., 2009). The lower peak intensity, demonstrates the decrease of pectin synthesis in root with increasing $\mathrm{ABA}, \mathrm{GA}_{3}$ and salt level but this decrease was more at lower concentrations (Fig. 4). On the other hand, the band intensity was higher in the shoot, indicating an increase in pectin synthesis with $\mathrm{ABA}, \mathrm{GA}_{3}$ and salt. In case of $\mathrm{ABA}$, the increase was more at $5 \mu \mathrm{M}$ but in $\mathrm{GA}_{3}$ and salt, the band intensity increased with increasing concentration of $\mathrm{GA}_{3}$ and salt (Fig. 5). A significant decrease of lipids in root was found with $\mathrm{ABA}, \mathrm{GA}_{3}$ and salt; and this decrease was more prominent at $5 \mu \mathrm{M} \mathrm{ABA}, 100 \mu \mathrm{M} \mathrm{GA}_{3}$ and $100 \mathrm{mM}$ salt (Fig. 4). The absorbance value was higher at lower concentrations of $\mathrm{ABA}$ but the value increased with increasing level of $\mathrm{GA}_{3}$ and salt (Fig. 5). It means that in rice seedling, the synthesis of cell wall and lipids is much more sensitive in root to $\mathrm{ABA}, \mathrm{GA}_{3}$ and salt stress as compared to shoot.

Expression of different variants of OsBTF3:To observe expression patterns of different variants of OsBTF3 in different tissues (callus, root, stem, leaf, leaf sheath, palea, lemma, stamen and pistil) including root and shoot at seedling stage through semi-quantitative. The results indicated that different variants of OsBTF3 were constitutively expressed in all plant parts (Fig. 6), indicating that OsBTF3 is essential for both vegetative growth and development in rice.

Early seedling is the most sensitive stage of vegetative growth and reproductive development for any crop. Therefore, to check the regulation of different variants of OsBTF3 in root and shoot at seedling stage under ABA (5 and $10 \mu \mathrm{M}), \mathrm{GA}_{3}(100$ and $200 \mu \mathrm{M})$ and $(100$ and $200 \mathrm{mM})$ salt stress, semi-quantitative PCR analyses were carried out using the OsBTF3-specific primers. The actin mRNA level was used as a control for RT-PCR.

The results show that the expression of Osj3g1BTF3 and Osj10gBTF3 was induced by low and high concentrations of ABA in shoot, but samples treated with $5 \mu \mathrm{M}$ ABA had less transcripts compared to controls in root. However, the transcript level of Osj3g2BTF3 did not change in root and shoot after treatment with 5uM ABA but the expression level slightly increased in root and shoot at $10 \mu \mathrm{M}$ ABA (Fig. 7).

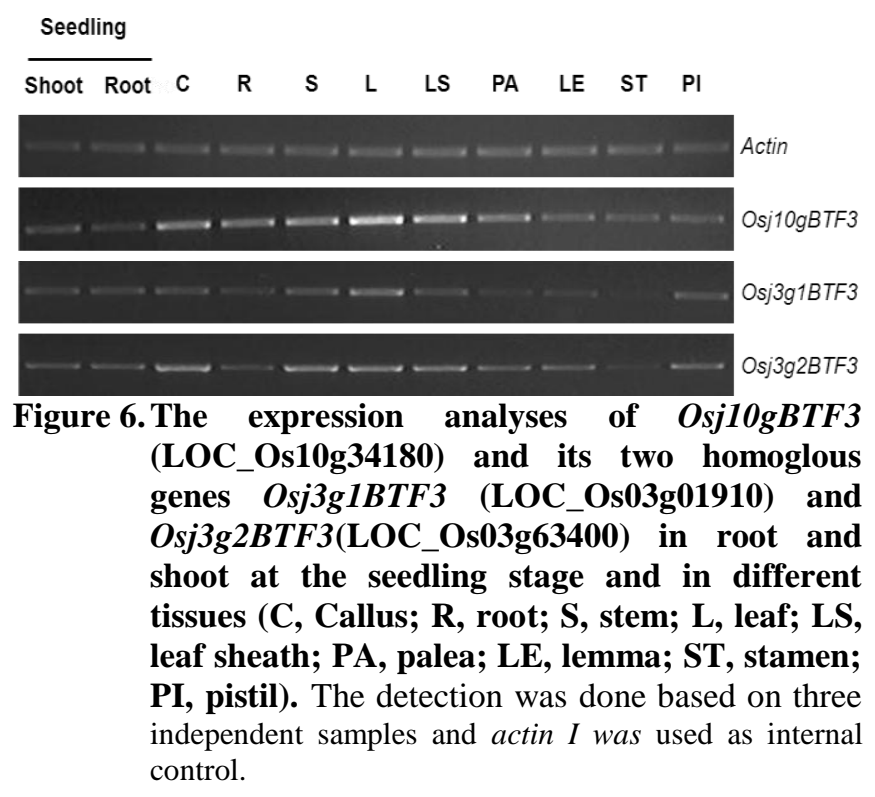

(A) $A B A(\mu M)$

(B) $\mathrm{GA} 3(\mu \mathrm{M})$

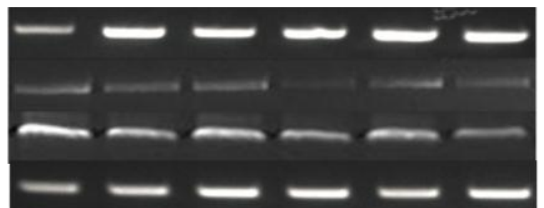

Osj3g2BTF3 Osj3g1BTF3 Osj10gBTF3 Actin

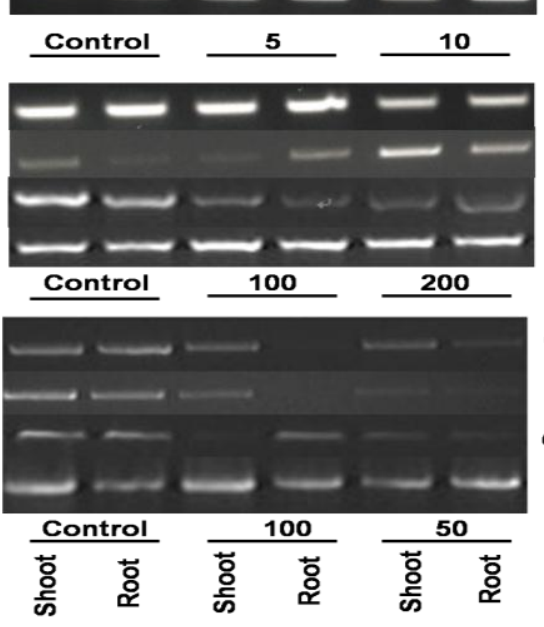

Osj3g2BTF3 Osj3g1BTF3 Osj10gBTF3 Actin

Osj3g2BTF3

(C) $\mathrm{NaCl}(\mathrm{mM})$ Osj3g1BTF3 Osj10gBTF3 Actin

Figure 7. The of Osj10gBTF3 
(LOC_Os10g34180) and its two homoglous genes Osj3g1BTF3 (LOC_Os03g01910) and Osj3g2BTF3 (LOC_Os03g63400) through semiquantitative PCR. In root and shoot under different concentration of $\mathrm{ABA}(\mathrm{A}) \mathrm{GA}_{3}$ (B) and $\mathrm{NaCl}$ (C). The detection was done based on three independent samples and actin I was used as internal control.

In Osj3g2BTF3 and Osj10gBTF3, the number of transcripts increased with increasing level of $\mathrm{GA}_{3}$ from 100 to $200 \mu \mathrm{M}$ in the shoot; however, the level appeared to significantly decrease in root at $200 \mathrm{M}$. In Osj3g2BTF3, the number of transcripts increased with increasing level of $\mathrm{GA}_{3}$ from 100 to $200 \mu \mathrm{M}$ in the shoot; however, the level appeared to significantly decrease in root at $100 \mu \mathrm{M}$, after which the expression level increased when treat with $200 \mu \mathrm{M}$ (Fig. 7).

In Osj3g2BTF3 and Osj10gBTF3, the samples treated with salt significantly up-regulated the transcript level with increasing $\mathrm{NaCl}$ from 50 to $100 \mathrm{mM}$ in shoot but the number of transcripts decreased with increasing level of $\mathrm{NaCl}$ from 50 to $100 \mathrm{mM}$ in the root. The transcript level of Osj3g2BTF3 did not change in shoot after treatment with $\mathrm{NaCl}$ but the expression level significantly decreased in root with increasing concentration (Fig. 7). These results show that the down regulation of the BTF3gene in root may reflect the compromised protein translation and importing activity under salt stress. For the hormone treatment, the induction effect showed by $\mathrm{ABA}$ and $\mathrm{GA}_{3}$ was much more significant in shoot than the repression effect caused by both in root. There was a difference between the shoot and root, indicating thatBTF3is more sensitive in root under abiotic stress conditions.

\section{DISCUSSION}

It has been documented that the germination, seedling growth and other related processes could be affected in seeds that are exposed to different environmental conditions (Gill and Singh, 1985). Variation in these processes can affect other metabolic activities, mainly the carbohydrate and protein metabolism that plays significant role in germination and seedling growth. In this study, application of $\mathrm{NaCl}$ as well as phytohormones $\left(\mathrm{GA}_{3}, \mathrm{ABA}\right)$ did not induce any significant decrease in germination. However, the decrease in germination rate was observed particularly under $\mathrm{NaCl}$ and $\mathrm{ABA}$ treatment (Fig. 1). Similarly, $\mathrm{ABA}$ and salt significantly reduced root and shoot length while $\mathrm{GA}_{3}$ enhanced shoot length with increasing concentration (Fig. 2, 3). This may be an adaptation approach of seeds to avoid embryo germination under different stress conditions, hence ensuring the appropriate organization of the seedlings by an increase in osmoregulatory compatible solutes (Thakur and Sharma, 2005). The dormancy-inducing hormone ABA, which is also known as the stress hormone, may also be involved in inhibiting the seed germination by reducing the accessibility of energy and metabolites (Garciarrubio et al., 2003).

For a better understanding of the salt and phytohormone effects on cell homeostasis, FT-IR spectroscopy were used to analyze changes in the macromolecular content such as carbohydrate, protein, lipids and cell wall pectin in plant root and shoot at early seeding stage. In this report, changes have been observed in the chemical composition of cells during seedling development in root and shoot under $\mathrm{GA}_{3}, \mathrm{ABA}$ and salt stress, although every individual peak could not endeavored to a particular secondary structure.

In response to $\mathrm{GA}_{3}, \mathrm{ABA}$ and salt stress, there was a general decrease in the protein and carbohydrate content in root suggested by a decline in the absorption bands intensity particularly in the 1800 to $1000 \mathrm{~cm}^{-1}$ region. In contrast, a significant increase in the protein and carbohydrate content in shoot showed by an increase in the peak of IR spectra in the same region (Fig. 4 and 5), as this region is specific for carbohydrate and proteins (Wolkers et al., 2004; Yee et al., 2004). The results indicated that the carbohydrate and protein synthesis is sensitive to $\mathrm{GA}_{3}, \mathrm{ABA}$ and $\mathrm{NaCl}$ stress in root than shoot at the seedling stage. Similar results were observed previously by using similar FT-IR technique for investigating variations in the chemical composition in higher plants and algae (Dokken et al., 2002; Yang and Yen, 2002). In Arabidopsis, the IR spectra indicated salinity can inflect the protein structure; however, a part of the leaf protein is sensitive, but not responsive to the increasing concentration of salt stress (Yang and Yen, 2002). It has been reported that cadmium stress can excite the metabolism of carbohydrate in the apricot and clover leaves (Elloumi et al., 2007; Wei et al., 2009), suggesting that the carbohydrate synthesis pathway or some carbohydrate may play a vital role in the anti-oxidative stress in shoot at the early seedling stage.

The IR spectrum around $1745 \mathrm{~cm}^{-1}$ represents cell wall pectin and band between 3000 and $2800 \mathrm{~cm}^{-1}$ mostly take place from lipids (Wei et al., 2009). The absorption peak situated in these regions showed the relative declining of cell wall pectin and lipid in root, after $\mathrm{GA}_{3}, \mathrm{ABA}$ and salt exposure. However, there was an increase in the accumulation of cell wall pectin and lipids in shoot in these regions (Fig. 4 and 5). These results simplify that cell wall pectin and lipid have accumulated in the shoot tissue but not in root. There were few reports on lipid and cell wall pectin by using FT-IR spectroscopy. Wei et al. (2009) observed a decrease in the band intensity indicating lipids and cell wall pectin synthesis was lowered after $1 \mathrm{hr} \mathrm{Cd}$ treatment in clover leaves. It has been documented that BTF3 play central role in plant growth and development (Wang et al., 2012). The seedling stage is one of the most important phases during a plant growth and development (Hanley et al., 2004). Therefore, in this study, the expression of different variants of BTF3 in root and shoot at the early 
seedling stage has been investigated. The expression of different variants of OsBTF3is primarily constitutive, being generally modulated by different GA3, ABA and salt stress treatments (Fig. 6, 7). The expression of Osj3g1BTF3, Osj3g2BTF3 and Osj10gBTF3 was induced by ABA and $\mathrm{GA}_{3}$ in shoot, but was repressed in root (Fig. 7). The salt concentration up-regulated Osj3g1BTF3 and Osj10gBTF3 expression with increasing $\mathrm{NaCl}$ from 50 and $200 \mathrm{mM}$ in shoot whereas salt concentrations did not change the transcript level of Osj3g2BTF3 in shoot but the expression level significantly decreased in root with increasing concentration (Fig. 7). These results demonstrated that the expression level of Osj3g1BTF3 and Osj10gBTF3 are much similar under abiotic stress condition but different from Osj3g2BTF3. It means that Osj10gBTF3 and Osj3g1BTF3 are probably similar but different from Osj3g2BTF3 in biological function as observed by Wang et al. (2012). In this case, a significant increase was reported in Osj10gBTF3 expression level with $\mathrm{ABA}$ and decrease in expression with $\mathrm{GA}_{3}$. Wang et al. (2012) also observed the transcript level of Osj10gBTF3 to be down-regulated under high salt concentration, while up-regulated under low salt concentrations in rice. Previously, it was observed that the expression level of NbBTF3 remains unaffected when treated with $100 \mu \mathrm{M}$ of $\mathrm{ABA}$ and $\mathrm{GA}_{3}$ (Yang et al., 2007). Zhang et al. (2010) demonstrated that ZmBTF3 expression in Zea mays were significantly decreased by using $100 \mu \mathrm{M}$ of ABA and $250 \mathrm{mM} \mathrm{NaCl}$. Li et al. (2012b) documented that transcript level of OsBTF3 was significantly decreased in rice plants under salt stress and the resistance to salt stress was improved in the seedlings of OsBTF3 transgenic lines.

Conclusion: This is a first report demonstrating the involvement of different variant of BTF3 in abiotic stress response in root and shoot at seedling stage. Further investigation is required to provide insight into the functions of BTF3 and the connected mechanisms that are responsible for improving abiotic stress tolerance in plants.

\section{REFERENCES}

Adhiya, J., X.H. Cai, R.T. Sayre and S. Traina. 2002. Binding of aqueous cadmium by the lyophilized biomass of Chlamydomonas reinhardtii. Colloids and Surfaces A: Physiochem. Eng. Aspect 210:1-11.

Allison, G.G., C. Morris, E. Hodgson, J. Jones, M. Kubacki T. Barraclough,N. Yates, I. Shield, A.V. Bridgwater and I.S. Donnison. 2009. Measurement of key compositional parameters in two species of energy grass by Fourier transform infrared spectroscopy. Bioresour. Technol. 100:6428-6433.

Beatrix, B., H. Sakai and M. Wiedmann. 2000. The alpha and beta subunit of the nascent polypeptide-associated complex have distinct functions. J. Biol. Chem. 275:37838-37845.

Dokken, K., L.C. Davis, L.E. Erickson and S. Castro. 2002. Fourier transform infrared spectroscopy as a tool to monitor changes in plant structure in response to soil contaminants. Proc. Waste Res. Technol. 7.

Elloumi, N., B.A. Ferjani, R. Ali, B.R. Bechir, M. Imed and B. Makki. 2007. Cadmium-induced growth inhibition and alteration of biochemical parameters in almond seedlings grown in solution culture. Acta Physiol. Plant. 29:57-62.

Freire, M.A. 2005. Translation initiation factor (iso) 4E interacts with BTF3, the beta subunit of the nascent polypeptide-associated complex. Gene 345:271-277.

Garciarrubio, A., J.P. Legaria and A.A. Covarrubias. 2003. Abscisic acid inhibits germination of mature Arabidopsis seeds by limiting the availability of energy and nutrients. Planta 2:182-187.

Gill, K.S. and O.S. Singh. 1985. Effect of salinity on carbohydrate metabolism during paddy (Oryza sativa) seed germination under salt stress condition. J. Expt. Biol. 23:384-6.

Gorantla, M., P.R. Babu, V.B.R. Lachagari, F.A. Feltus, A.H. Paterson and A. Reddy. 2005. Functional genomics of drought-stress response in rice: transcript mapping of annotateduni genes of an indica rice (Oryza sativa L. cv. Nagina 22). Curr. Sci. 289:496-514.

Griffiths, P.R. and J.A. de Haseth. 1986. Fourier Transform Infrared Spectrometry. John Wiley and Sons, New York. pp. 45-52.

Hanley, M.E., M. Fenner, H. Whibley and B. Darvill. 2004. Early plant growth: identifying the end point of the seedling phase. New Phytol. 163:61-66.

Huh, S.U., K.J. Kim and K.H. Paek. 2012. Capsicum annuumbasic transcription factor 3 (CaBTF3) regulates transcription of pathogenesis-related genes during hypersensitive response upon tobacco mosaic virus infection. Biochem. Biophys. Res. Commun. 417:910917.

Hussain, S.S., M.A. Kayani and M. Amjad. 2011. Transcription factors as tools to engineer enhanced drought stress tolerance in plants. Biotechnol. Progress 27:297-306.

Koster, K.L. and A.C. Leopold. 1988. Sugar and desiccation tolerance in seeds. Plant Physiol. 88:829-832.

Mayer, A.M. and A. Poljakoff-Mayber. 1975. The Germination of Seeds. Pergamon Press, New York.

Li, G.X., M.S. Wu and C.Y. He. 2009. Gene expression response of transcription factor OsBTF3 in rice to bacterial and fungal infection and signal molecule treatment revealed by quantitative real-time PCR analysis. ActaPhytopathol. Sinica39:272-277.

Li, G.X., J. Wu, M.S. Wu and C.Y. He. 2012a. Resistance to high salt and cold stress of transgenic rice seedlings 
with over-expressed and RNAi-silenced OsBTF3. Chin. J. Rice Sci. 26:5-8.

Li, G.X., H.M. Chen, M.S. Wu and C.Y. He. 2012 b. Responses and expression of defense genes of transgenic rice with over-expressed or RNAi-silenced OsBTF3 gene upon bacterial infection. ActaPhytopathol. Sinica42:169-175.

Ma, H.Z., G.Q. Liu, C.W. Li, G.Z. Kang and T.C. Guo. 2012. Identification of the TaBTF3 gene in wheat (TriticumaestivumL.) and the effect of its silencing on wheat chloroplast, mitochondria and mesophyll cell development. Biochem. Biophys. Res. Commun. 426:608-614.

McCann M., C., M. Hammouri, R. Wilson, P. Belton and K. Roberts. 1992. Fourier transform infrared microspectroscopy is a new way to look at plant cell walls. Plant Physiol. 100:1940-1947.

Sheng, P.X., Y.P. Ting, J.P. Chen and L. Hong. 2004. Sorption of lead, copper, cadmium, Zinc and nickel by marine algal biomass: characterization of biosorptive capacity and investigation of mechanisms. J. Coll. Inter. Sci. 275:131-141.

Stehfest, K., J. Toepel and C. Wilhelm. 2005. The application of micro-FTIR spectroscopy to analyze nutrient stress-related changes in biomass composition of phytoplankton algae. Plant Physiol. Biochem. 43:717-726.

Stewart, D., N. Yahiaoui, G.J. McDougall, K. Myton, C. Marque, A.M. Bouder and J. Haigh. 1997. Fouriertransform infrared and Raman spectroscopic evidence for the incorporation of cinnamaldehydes into the lignin of transgenic tobacco (NicotianatabacumL.) plants with reduced expression of cinnamyl alcohol dehydrogenase. Planta 201:311-318.

Surewicz, W.K., H.H. Mantsch and D. Chapman. 1993. Determination of protein secondary structure by fourier transform infrared spectroscopy: A critical assessment. Biochem. 32:389-393.

Thakur, M. and A.D. Sharma. 2005. Salt-stress-induced proline accumulation in germinating embryos: Evidence suggesting a role of proline in seed germination. J. Arid Environ. 62:517-523.
Wang, Y., X. Zhang, S. Lu, M. Wang, L. Wang, W. Wang, F. Cao, H. Chen, J. Wang, J. Zhang and J. Tu. 2012. Inhibition of a basal transcription factor 3-like gene Osj10gBTF3 in rice results in significant plant miniaturization and typical pollen abortion. Plant Cell Physiol. 53:2073-2089.

Wei, Z.I., I. Dong and Z.H. Tian. 2009. Fourier Transform Infrared Spectrometry study on early stage of cadmium stress in clover leaves. Pak. J. Bot. 41:1743-1750.

Wiedmann, B., Sakai, T.A. Davis and M. Wiedmann. 1994. A protein complex required for signal-sequence-specific sorting and translocation. Nature 370:434-440.

Wolkers, W.F., A.E. Oliver, F. Tablin and J.H. Crowe. 2004. Afourier transform infrared spectroscopy study of sugar glasses. Carb. Res. 339:1077-1085.

Yang, K.S., H.S. Kim, U.H. Jin, S.S. Lee, J.A. Park and Y.P. Lim. 2007. Silencing of NbBTF3 results in developmental defects and disturbed gene expression in chloroplasts and mitochondria of higher plants. Planta 225:1459-1469.

Yang, J. and H.C.E. Yen. 2002. Early salt stress effects on the changes in chemical composition in leaves of ice plant and Arabidopsis: A fourier transform infrared spectroscopy study. Plant Physiol. 130:1032-1042.

Yee, N., L.G. Benning, V.R. Phoenix and F.G. Ferris. 2004. Characterization of metal-Cyanobacteria sorption reactions: A combined macroscopic and infrared spectroscopic investigation.Environ. Sci. Technol. 38:775-782.

Zhang, Z.B., D.F. Zhang, H.Y. Li, Y.H. Liu, Y.S. Shi, Y.C. Song, T.Y. Wang and Y. Li. 2010. Isolation and expression analysis of a drought-induced gene ZmBTF3b in maize (Zea mays L.). Sci. Agri. Sinica 43:3280-3287.

Zheng, X.M., D. Black, P. Chambon and J.M. Egly. 1990. Sequencing and expression of complementary DNA for the general transcription factor BTF3. Nature 344:556559.

Zhou, M.L., J.T. Ma, J.F. Pang, Z.L. Zhang, Y.X. Tang and Y.M. Wu. 2010. Regulation of plant stress response by dehydration responsive element binding (DREB) transcription factors. Afr. J. Biotechnol. 9:9255-9279. 